\title{
INFLUENCE OF SOME FACTORS ON DAILY MILK PRODUCTION IN AWASSI BREED OF SHEEP IN MACEDONIA
}

\author{
Nikola Pacinovski ${ }^{1}$, Elena Eftimova ${ }^{1}$, Nataša Mateva ${ }^{1}$, Bone Palaševskii ${ }^{1}$, \\ Goce Cilev ${ }^{2}$, Nikola Adamov ${ }^{3}$ \\ 1 "Ss. Cyril and Methodius” University in Skopje, Institute of Animal Science, \\ Blvd. Ilinden, 92a, 1000 Skopje, Republic of Macedonia \\ 2 "St. Clement of Ohrid” University of Bitola, Veterinary Faculty, \\ Prilepska bb, 7000 Bitola, Republic of Macedonia \\ 3 "Ss. Cyril and Methodius" University in Skopje, Faculty of Veterinary Medicine, \\ Lazar Pop Trajkov, 1000 Skopje, Republic of Macedonia \\ npacinovski@yahoo.com
}

\begin{abstract}
Several production traits of the daily milk yield (morning, noon, evening and total milk, \% and amount of fats) for total of 170 heads of Awassi sheep, were analyzed during four production years (2002, 2003, 2004 and 2005). In total 1130 lactation test days were included in the study. The ewes were at the age from first to eleventh lactation. All the data were analyzed by multi-factor fixed model. The certain factor influence was studied with the F-test. The analyses were made with the set of programs SPSS (SPSS, 1994). Almost all factors (year, lactation, lambing month, month of milk control, milk control number), except fertility, had highly significant influence $(\mathrm{P}<0.001)$ on daily milk production (morning, noon, evening and total milk, $\%$ and amount of fats) in tested sheep population. The highhighest daily milk production was determined in sheep at their $8^{\text {th }}$ lactation and the lowest at those at $11^{\text {th }}$ lactation. Analogically to this data, the sheep of the same age produced the highest and lowest fat amount, respectively. The influence of lactation, confirmed that Awassi breed maintaines the level of high and standard milk production in older age. A typical lactation curve was determined in tested dairy sheep which starts with the highest daily lactation yield during the first milk control, and diminishes during lactation to the lowest of the last one.
\end{abstract}

Key words: Awassi; daily milk production; factors influence; lactation curve

\section{ВЛИЈАНИЕ НА НЕКОИ ФАКТОРИ ВРЗ ДНЕВНОТО ПРОИЗВОДСТВО НА МЛЕКО КАЈ ОВЦИ ОД РАСАТА АВАСИ ВО РЕПУБЛИКА МАКЕДОНИЈА}

Кај вкупно 170 овци од расата аваси се испитувани неколку производни својства во текот на четири производни години $(2002,2003,2004$ и 2005). Во текот на целнот контролен период се реализирани вкупно 1130 лактациски контроли кај овци на возраст од прва до единаесетта лактација. Сите податоци се анализирани со помош на многуфакторен фиксен модел. Влијанието на одделните фактори е проучувано со помош на F-тестот. Анализите се правени со помош на пакет програми SPSS. Речиси сите испитувани фактори (година, лактација, месец на јагнење, месец на контрола на млеко, број на контола) освен плодноста имаа високосигнификантно влијание $(\mathrm{P}<0,001)$ врз дневното производство на млеко (утринско, пладневно, вечерно и вкупно млеко, \% и количина на маст) кај испитуваната популација овци. Највисоко дневно производство на млеко е утврдено кај овците во 8-мата, а најниско кај оние во 11-тата лактација. Соодветно на овој податок, овците од истата возраст произведоа најголема, односно најмала количина маст. При утврдување на влијанието на лактацијата се потврди фактот дека расата аваси го задржува нивото на високо и стандардно производство на млеко до поодмината возраст. Кај испитуваните овци е утврдена типична лактациска крива, карактеристична за млечните раси овци, која почнува со највисока дневна млечност при првата контрола на млеко, а најниска при последната. 


\section{INTRODUCTION}

The selection as constant process, is the safest way to accomplishing the genetic progress in the population (Petrovič et al., 2005), and according to some authors it is also the best tool for maintaining of the biodiversity (Kosgey, 2004). However, this method is quite slow, as a consequence of the biological limit of sheep reproduction and generation interval (Mekič et al., 2005). In this case the crossbreeding insures faster improvement of the genetic potential.

Having in mind the Macedonian farmer tradition of the sheep breeders regarding their background, the basic direction for importing and using the dairy breeds in Republic of Macedonia (East Frisian, Awassi, Chios, Sardinian) is to milk the sheep.

There are 440 breeds in the world (FAO, 2007), but only few (East Frisian, Awassi, Lacon, British milk sheep, Chios, Sardinian, Plevenska Blackhead sheep) belong to the group dairy sheep breeds.

In this context one of the most used dairy breeds for improving the milk production of the domestic sheep population in Republic of Macedonia is the Awassi breed, present in the country for almost 4 decades (Pacinovski, 2010).

The objective of this study was to determine the level of influence of certain factors on daily milk production (morning, noon, evening and total milk), as well as the percent and amount of pro- duced milk fat every control day, in pure bred Awassi breed.

\section{MATERIAL AND METHODS}

Basic testing material was the Awassi breed of sheep, raised in the unique reproductive center for this breed in Gradishte, Kumanovo.

Data were collected in the period of 4 production years, i.e. in the period of 2002-2005. During the whole control period in total 170 heads were tested (Table 1).

Table 1

Number of tested sheep per year

\begin{tabular}{lccccc}
\hline \hline \multirow{2}{*}{ Population } & \multicolumn{5}{c}{ Year } \\
\cline { 2 - 6 } & 2002 & 2003 & 2004 & 2005 & Total \\
\hline Awassi & 33 & 37 & 38 & 62 & 170 \\
\hline \hline
\end{tabular}

According to the age structure, it was a relatively young herd, where most of the sheep were in first lactation (46), and the rest were between second and fifth lactation. Very small part of the sheep was at the age of $6^{\text {th }}$ to $11^{\text {th }}$ lactation. The age structure of the tested sheep is shown on Table 2.

During the control years, total of 1130 controls of the daily lactation yield were made, i.e. 274 in the first, 176 in the second, 158 in the third etc. lactation years (Table 3).

Table 2

The age structure of the tested sheep per year

\begin{tabular}{ccccccccccccc}
\hline \hline \multirow{2}{*}{ Year } & \multicolumn{10}{c}{ Lactation in order } \\
\cline { 2 - 12 } & I & II & III & IV & V & VI & VII & VIII & IX & X & XI & Total \\
\hline 2002 & - & 9 & 6 & 11 & - & 1 & 3 & 2 & 1 & - & - & 33 \\
2003 & 11 & - & 8 & 5 & 11 & - & - & 2 & - & - & - & 37 \\
2004 & 15 & 5 & - & 8 & 3 & 7 & - & - & - & - & - & 38 \\
2005 & 20 & 12 & 9 & - & 8 & 2 & 8 & - & - & 2 & 1 & 62 \\
\hline Total & 46 & 26 & 23 & 24 & 22 & 10 & 11 & 4 & 1 & 2 & 1 & 170 \\
\hline \hline
\end{tabular}

Table 3

Individual lactation tests in Awassi sheep for the period 2002-2005

\begin{tabular}{cccccccccccc}
\hline \hline & & \multicolumn{11}{c}{ Lactation in order } & & & & & \\
\hline I & II & III & IV & V & VI & VII & VIII & IX & X & XI & Total \\
\hline 274 & 176 & 158 & 168 & 160 & 69 & 73 & 28 & 9 & 10 & 5 & 1130 \\
\hline \hline
\end{tabular}


The individual lactation yield in these sheep was observed according to a standard A4 method (ICAR, 2012), which comprises measuring of the total amount of milk in interval of 28 to 34 days.

The lactation controls start 10 days after lambing and last until the middle of October, when majority of ewes were dry. The number of performed lactation control days were in average 8, and during every lactation control a aggregate individual milk sample of $50 \mathrm{ml}$ was taken (at least $25 \mathrm{ml}$ of every milking) for analysis of the fat percentage. The milk composition was analyzed by milk analyzer, Milkoscan FT 6000.

Every control day six different traits were collected in purebred Awassi sheep (morning, noon, evening and total daily milk yield, as well as the percent and the amount of milk fat). The average value of each of these traits is determined based on the 1130 individual lactation controls (Table 3).

The daily milk production traits (morning, noon, evening, total, fat $\%$ and fat $\mathrm{kg}$ ) were analyzed by the following multitrait fixed model:

$$
Y_{j k l m n o}=\mu+Y_{j}+L_{k}+M B_{l}+T D_{m}+T M_{n}+F_{o}+e_{j k l m n o}
$$

where:

$Y$ - the individual observation of every trait during a test (daily) control (morning, noon, evening and total milk, fat milk \% and fat milk $\mathrm{kg}$ );

$\mu-$ a general, common average for tested traits; and 2005);
$L_{k}-$ effect of $k$-th lactation $(k=1,2,3,4,5,6$, $7,8,9,10,11)$

$M B_{l}$ - effect of $l$-th month of lambing $(l=$ November, December, January, February, March, April, May, June, July);

$T D_{m}$ - effect of $m$-th test day $(m=1,2,3,4$, $5,6,7,8,9)$;

$T M_{n}-$ effect of $n$-th month of test ( $n=$ January, February, March, April, May, June, July, August, September, October, November);

$F_{o}$ - effect of fertility, e.g. of the $o$-th number of newborn lambs $(o=1,2)$;

$e_{j k l m n o}-$ residual influence.

The influence of the effects was studied by $F$ test. The analyses were made by the set of programs SPSS (SPSS, 1994).

\section{RESULTS AND DISCUSSION}

\section{Average values of traits}

The average lactation yield of Awassi sheep for the four analyzed years is $325 \pm 14.864$ litres (Table 4), while the quantity of milk consumed by the lambs in average is $89 \pm 1.374$ litres. The production of commercial milk at this population in average for the four years is $236 \pm 14.737$ litres, while the average length of the suckling period is $74 \pm 1.145$ days. The length of the lactation period at this population for the four analyzed years in average is $234 \pm 3.90$ days.

Table 4

Descriptive statistics data of investigated Awassi ewes dairy traits, LS - mean $\pm S E$

\begin{tabular}{lcccccc}
\hline \hline Parametar & $n$ & Mean & Min. & Max. & Std. deviation & CV \\
\hline Lactation milk (litres) & 43 & $325 \pm 14.864$ & 135 & 567 & 90.17 & 27.74 \\
Suckling milk (litres) & 43 & $89 \pm 1.374$ & 72.90 & 107.70 & 10.07 & 11.31 \\
Commercial milk (litres) & 43 & $236 \pm 14.737$ & 70.77 & 475.92 & 74 & 31.36 \\
Length of suckling period (days) & 43 & $74 \pm 1.145$ & 60.75 & 89.75 & 8.37 & 11.31 \\
Length of lactation (days) & 43 & $234 \pm 3.90$ & 133.8 & 283.5 & 37.06 & 15.84 \\
Morning milk yield (litres) & 1130 & $0.680 \pm 0.040$ & 0.06 & 2.10 & 0.34 & 50 \\
Noon milk yield, (litres) & 1130 & $0.207 \pm 0.030$ & 0.10 & 1.50 & 0.21 & 101.45 \\
Evening milk yield (litres) & 1130 & $0.501 \pm 0.040$ & 0.05 & 1.80 & 0.28 & 55.89 \\
Fat (\%) & 1130 & $7.62 \pm 0.11$ & 4.00 & 11.00 & 1 & 13.12 \\
Daily fat yield (kg) & 1130 & $0.105 \pm 0.010$ & 0.013 & 0.313 & 0.05 & 47.62 \\
\hline \hline
\end{tabular}


Results for the lactation milk (325 llitres), at Awassi sheep are in correspondence with the statements and results of big number other authors that have been working on determination of milk production of this breed of sheep (Hristov, 1983; Todorovski et al., 1984; Epstein, 1985; Gootwine, 1995; Elicin and Ertugrul - quote Gursoy et al., 1995; De la Fuente et al., 2006; Kukovics et al., 2006; Amin and Peters, 2006, and others).

Results from this study regarding the average daily milk production (Table 4) in this sheep population are within the expected once and they are in accordance with the literature data. According to Todorovski et al. (1973) daily production was insignificantly higher in newly imported flock of purebreed Awassi sheep from Israel, average daily milk production was 1.72 litres, with a maximal value of 3.07 litres. It is necessary to emphasize that regarding the average milk production data from previous study are slightly higher regarding our data, but we noted higher maximal daily milk production, also for the four years, respectively $(3.75,3.40,3.20$ and 4.50). In other tests, Todorovski et al. (1985) determined average daily milk production of $1.004 \mathrm{~kg}$ in Awassi sheep, which is lower than the one determined in our tests, in terms of the testing years. Same authors (Todorovski et al. 1984) determined average daily milk production of 1.32 litres in Awassi sheep, which is almost identical with our test results. Comparing the daily milk production of this population sheep with other dairy breeds differences can be noted, McKusick et al. (2001) determined maximal milk production (i.e. pick milk production) of $2.93 \mathrm{~kg}$ in EastFriesian sheep.

These results are close with the findings of several authors: Srour et al. (2006) determined average percent of $6.9 \%$ milk fat, Caja et al. (2006) determined average percent of milk fat of $6.52 \%$ in
Awassi sheep in Spain, Iniguez et al. (2006) determined average fat of $6.51 \%$ in Turkish Awassi sheep, Mavrogenis (1995) determined 7.3\% milk fat in Awassi breed in Cyprus, according to Nudda et al. (2002), the average milk fat in breed Awassi is $7.48 \%$. According to Hristov (1983), the average milk fat in newly imported flock of Awassi sheep in Bulgaria in 1979 is from 6.71 up to $9.05 \%$, and Todorovski et al. (1973) concluded 6.48\% milk fat in purebreed Awassi sheep in Macedonia with variations from 6.1 to $7.5 \%$. The average percent of milk fat in Awassi sheep can be very variable, in two different studies Todorovski noted different values. In the first study a value of $6.8 \%$ was determined as an average (Todorovski et al., 1996) and in the second one $7.73 \%$ was noted as an average value for milk fat (Todorovski et al., 1979).

\section{Influence of the factors}

Almost every tested factor influences highly significantly $(\mathrm{P}<0.001)$ on daily milk production in Awassi sheep (Table 5), as well as on the composition and relative representation of milk fat. Only fertility does not have influence $(\mathrm{P}>0.05)$ on the variation of tested traits (morning and noon milk production, fat percent), except for the total and evening milk, as well as the content of the milk fat, where influence $(\mathrm{P}<0.05)$ of level is shown.

The determination coefficient for the tested traits in this breed is from 0.460 for evening milk up to 0.729 for noon milk.

The influence of these factors in details is shown in the next tables (Table 6 - Table 11).

\section{Year influence on daily milk production in Awassi sheep population}

The year has a significant influence $(\mathrm{P}<0.001)$ on tested traits of daily milk production in Awassi sheep (Table 6).

Table 5

Factors influence on the daily milk production in Awassi sheep, F-test and its significance (F-statistics)

\begin{tabular}{lccccccc}
\hline \hline Factor & Df & Morning & Noon & Evening & Total & Fat $(\%)$ & Fat $(\mathrm{kg})$ \\
\hline Year & 3 & $29.708^{* * *}$ & $76.435^{* * *}$ & $17.261^{* * *}$ & $3.908^{* * *}$ & $145.03^{* * *}$ & $10.597^{* * *}$ \\
Lactation & 10 & $4.913^{* * *}$ & $3.115^{* * *}$ & $3.508^{* * *}$ & $6.624^{* * *}$ & $3.313^{* * *}$ & $7.229^{* * *}$ \\
Month of lambing & 8 & $2.752^{* *}$ & $1.428^{\mathrm{ns}}$ & $8.885^{* * *}$ & $5.670^{* * *}$ & $4.031^{* * *}$ & $6.183^{* * *}$ \\
Month of milk control & 10 & $7.893^{* * *}$ & $38.218^{* * *}$ & $13.136^{* * *}$ & $9.739^{* * *}$ & $16.537^{* * *}$ & $8.624^{* * *}$ \\
No of milk control & 8 & $7.072^{* * *}$ & $15.509^{* * *}$ & $2.066^{*}$ & $5.853^{* * *}$ & $6.651^{* * *}$ & $3.225^{* * *}$ \\
Fertility & 1 & $1.751^{\mathrm{ns}}$ & $2.710^{\mathrm{ns}}$ & $3.646^{*}$ & $4.952^{*}$ & $0.054^{\mathrm{ns}}$ & $5.925^{*}$ \\
$\mathrm{R}^{2}-$ Coeff.. determination & $/$ & 0.574 & 0.729 & 0.460 & 0.670 & 0.599 & 0.628 \\
\hline \hline
\end{tabular}


According the data in Table 6, the total daily milk production in this population is highest in 2002 (1.50 \pm 0.07 litres), and lowest in 2004 (1.32 \pm 0.09 litres). The percent of milk fat is highest in
$2004(8.44 \pm 0.13 \%)$ and lowest in $2005(7.23 \pm$ $0.14 \%$, while the daily production of milk fat in $\mathrm{kg}$ is equalized and is from 0.10 to $0.11 \mathrm{~kg}$ for the four controlled years.

Table 6

The year influence on the daily milk production in Awassi sheep, LS - mean $\pm S E$

\begin{tabular}{cccccccc}
\hline \hline Year & $n$ & $\begin{array}{c}\text { Morning } \\
\text { (litres) }\end{array}$ & $\begin{array}{c}\text { Noon } \\
\text { (litres) }\end{array}$ & $\begin{array}{c}\text { Evening } \\
\text { (litres) }\end{array}$ & $\begin{array}{c}\text { Total } \\
\text { (litres) }\end{array}$ & $\begin{array}{c}\text { Fat } \\
(\%)\end{array}$ & $\begin{array}{c}\text { Fat } \\
(\mathrm{kg})\end{array}$ \\
\hline 2002 & 33 & $0.80 \pm 0.04$ & $0.31 \pm 0.03$ & $0.39 \pm 0.03$ & $1.50 \pm 0.07$ & $7.49 \pm 0.10$ & $0.11 \pm 0.01$ \\
2003 & 37 & $0.77 \pm 0.04$ & $0.03 \pm 0.03$ & $0.54 \pm 0.04$ & $1.34 \pm 0.08$ & $7.33 \pm 0.12$ & $0.10 \pm 0.01$ \\
2004 & 38 & $0.53 \pm 0.05$ & $0.21 \pm 0.04$ & $0.58 \pm 0.05$ & $1.32 \pm 0.09$ & $8.44 \pm 0.13$ & $0.11 \pm 0.01$ \\
2005 & 62 & $0.63 \pm 0.06$ & $0.28 \pm 0.04$ & $0.50 \pm 0.05$ & $1.41 \pm 0.10$ & $7.23 \pm 0.14$ & $0.10 \pm 0.01$ \\
\hline \hline
\end{tabular}

The morning milk yield is the highest for 2002 (0.80 litres) and the lowest in 2004 (0.53 litres). The amount of milk at noon varied among the years. It is in the scope of $0.21-0.31$ litres, which is reasonable taking into account the short interval between the morning and noon milking. Much lower was the noon yield for the 2003 year which was due not to the potential of the sheep, then to some nutritional reasons.

The evening milk yields also vary from 0.39 litres in 2002 to 0.58 litres in 2004. Obviously, for different years of control the general conditions differ (feeding, climate, organization of the milking, interval between separate milkings during the day). The variations in the milk yield during the separate milkings show that the applied in this study method is the most accurate one. However, due to the considerable labour that it requires for breeding purposes in most cases the AC method is preferred, which considers the measurement of the individual yield only once in the day of test and uses a correction factor with the total daily yield. Data from this study might be extended to similar studies in the future.

\section{Lactation influence on daily milk production in Awassi sheep}

The lactation, i.e. the age influences significantly highly $(\mathrm{P}<0.001)$ on all tested traits in Awassi sheep (Table 5). The total daily milk production in this population, starting from the second lactation, exclusion was made in third up to $8^{\text {th }}$ lactation. The lactation constantly decreases from $9^{\text {th }}$ to $11^{\text {th }}$ lactation. The highest percent of milk fat is noted in sheep which are in the $8^{\text {th }}$ lactation $(8.23 \pm$ $0.16 \%$, while the lowest percent is noted in the eleventh lactation $(7.10 \pm 0.32 \%)$ (Table 7).

Table 7

The lactation influence on the daily milk production in Awassi sheep, LS - mean $\pm S E$

\begin{tabular}{cccccccc}
\hline \hline Lactation & $n$ & $\begin{array}{c}\text { Morning } \\
\text { (litres) }\end{array}$ & $\begin{array}{c}\text { Noon } \\
\text { (litres) }\end{array}$ & $\begin{array}{c}\text { Evening } \\
\text { (litres) }\end{array}$ & $\begin{array}{c}\text { Total } \\
\text { (litres) }\end{array}$ & $\begin{array}{c}\text { Fat } \\
(\%)\end{array}$ & $\begin{array}{c}\text { Fat } \\
(\mathrm{kg})\end{array}$ \\
\hline 1 & 274 & $0.75 \pm 0.04$ & $0.20 \pm 0.03$ & $0.58 \pm 0.04$ & $1.53 \pm 0.08$ & $7.67 \pm 0.12$ & $0.12 \pm 0.01$ \\
2 & 176 & $0.79 \pm 0.05$ & $0.24 \pm 0.03$ & $0.58 \pm 0.04$ & $1.61 \pm 0.10$ & $7.78 \pm 0.12$ & $0.13 \pm 0.01$ \\
3 & 158 & $0.74 \pm 0.05$ & $0.22 \pm 0.03$ & $0.55 \pm 0.04$ & $1.51 \pm 0.09$ & $7.61 \pm 0.13$ & $0.11 \pm 0.01$ \\
4 & 168 & $0.75 \pm 0.05$ & $0.26 \pm 0.03$ & $0.58 \pm 0.04$ & $1.59 \pm 0.08$ & $7.78 \pm 0.12$ & $0.12 \pm 0.01$ \\
5 & 160 & $0.79 \pm 0.05$ & $0.25 \pm 0.03$ & $0.58 \pm 0.04$ & $1.62 \pm 0.08$ & $7.63 \pm 0.12$ & $0.12 \pm 0.01$ \\
6 & 69 & $0.78 \pm 0.05$ & $0.25 \pm 0.04$ & $0.59 \pm 0.05$ & $1.62 \pm 0.10$ & $7.61 \pm 0.14$ & $0.12 \pm 0.01$ \\
7 & 73 & $0.80 \pm 0.06$ & $0.25 \pm 0.04$ & $0.58 \pm 0.05$ & $1.63 \pm 0.10$ & $7.50 \pm 0.14$ & $0.12 \pm 0.01$ \\
8 & 28 & $0.82 \pm 0.06$ & $0.29 \pm 0.04$ & $0.55 \pm 0.06$ & $1.66 \pm 0.12$ & $8.23 \pm 0.16$ & $0.14 \pm 0.01$ \\
9 & 9 & $0.60 \pm 0.10$ & $0.27 \pm 0.07$ & $0.52 \pm 0.09$ & $1.39 \pm 0.18$ & $7.74 \pm 0.25$ & $0.11 \pm 0.01$ \\
10 & 10 & $0.39 \pm 0.010$ & $0.03 \pm 0.07$ & $0.32 \pm 0.09$ & $0.74 \pm 0.18$ & $7.20 \pm 0.25$ & $0.05 \pm 0.01$ \\
11 & 5 & $0.27 \pm 0.12$ & $0.04 \pm 0.09$ & $0.08 \pm 0.11$ & $0.39 \pm 0.23$ & $7.10 \pm 0.32$ & $0.03 \pm 0.02$ \\
\hline \hline
\end{tabular}


Cappio-Borlino et al. (1997) performed similar tests with ours by ,test-day” and they determined that lactation in order, i.e the age has influence on the milk fat and protein percent, but still lower that the one in the milk production. According to these authors, the lambing season also had influence on the fat and protein content.

\section{Lambing month influence \\ on daily milkproduction in Awassi sheep}

The lambing month in almost all tested parameters in Awassi sheep has shown a highly significant influence $(\mathrm{P}<0.001)$, except in the noon milking, where this factor did not show a signifi- cant influence ( $\mathrm{P}>0.05)$, (Table 5). The highest daily milk production is noted in those sheep which are lambed in May (1.84 \pm 0.13 litres), and lowest in those which are lambed in December (1.08 \pm 0.12 litres), (Table 8).

The milk fat percent is from $6.53 \pm 0.31 \%$ (in sheep which were lambing in July) up to $8.40 \pm$ $0.43 \%$ (in sheep which were lambing in June). The average amount of daily produced milk fat in Awassi sheep was $0.09 \mathrm{~kg}$ in sheep which were lambing in December, January and July, to $0.14 \pm$ 0.01 in sheep which were lambing in May. Results are similar to that of the Awassi in Israel (Gootwine and Pollott, 2000).

Table 8

The influence of the month of lambing on daily milk production in Awassi sheep, LS - mean $\pm S E$

\begin{tabular}{cccccccc}
\hline \hline Month of lambing & $n$ & $\begin{array}{c}\text { Morning } \\
\text { (litres) }\end{array}$ & $\begin{array}{c}\text { Noon } \\
\text { (litres) }\end{array}$ & $\begin{array}{c}\text { Evening } \\
\text { (litres) }\end{array}$ & $\begin{array}{c}\text { Total } \\
(\text { litres })\end{array}$ & $\begin{array}{c}\text { Fat } \\
(\%)\end{array}$ & $\begin{array}{c}\text { Fat } \\
(\mathrm{kg})\end{array}$ \\
\hline 11 & 8 & $0.72 \pm 0.11$ & $0.23 \pm 0.08$ & $0.48 \pm 0.10$ & $1.43 \pm 0.20$ & $7.05 \pm 0.28$ & $0.10 \pm 0.02$ \\
12 & 24 & $0.59 \pm 0.07$ & $0.19 \pm 0.05$ & $0.30 \pm 0.06$ & $1.08 \pm 0.12$ & $7.91 \pm 0.17$ & $0.09 \pm 0.01$ \\
1 & 318 & $0.58 \pm 0.03$ & $0.22 \pm 0.02$ & $0.39 \pm 0.02$ & $1.19 \pm 0.05$ & $7.82 \pm 0.07$ & $0.09 \pm 0.03$ \\
2 & 400 & $0.61 \pm 0.03$ & $0.24 \pm 0.02$ & $0.41 \pm 0.03$ & $1.26 \pm 0.06$ & $7.73 \pm 0.08$ & $0.10 \pm 0.004$ \\
3 & 230 & $0.65 \pm 0.04$ & $0.24 \pm 0.02$ & $0.46 \pm 0.03$ & $1.35 \pm 0.07$ & $7.76 \pm 0.09$ & $0.10 \pm 0.01$ \\
4 & 89 & $0.75 \pm 0.05$ & $0.26 \pm 0.04$ & $0.66 \pm 0.05$ & $1.67 \pm 0.10$ & $7.75 \pm 0.14$ & $0.13 \pm 0.01$ \\
5 & 50 & $0.84 \pm 0.07$ & $0.21 \pm 0.05$ & $0.79 \pm 0.06$ & $1.84 \pm 0.13$ & $7.66 \pm 0.18$ & $0.14 \pm 0.01$ \\
6 & 3 & $0.63 \pm 0.17$ & $0.20 \pm 0.12$ & $0.48 \pm 0.15$ & $1.31 \pm 0.31$ & $8.40 \pm 0.43$ & $0.11 \pm 0.02$ \\
7 & 8 & $0.74 \pm 0.12$ & $0.06 \pm 0.08$ & $0.55 \pm 0.11$ & $1.35 \pm 0.23$ & $6.53 \pm 0.31$ & $0.09 \pm 0.02$ \\
\hline \hline
\end{tabular}

\section{Influence of month of test} on daily milk production of Awassi sheep

The month of milk test has highly significant influence $(\mathrm{P}<0.001)$ on every trait of Awassi sheep (Table 5). The amount of milk in morning, noon and total milk decreases constantly from the $1^{\text {st }}$ (January) until the $11^{\text {th }}$ (November) milk control (Table 9). The milk during noon milking is an exception because it increases from the first (January) to the third (March) month of milk control, and decreases constantly from $4^{\text {th }}$ (April) until the last, i.e. the $11^{\text {th }}$ lactation month (November). The milk fat percent decreases from the $1^{\text {st }}$ to the $3^{\text {rd }}$ month of milk production, the lowest is the $4^{\text {th }}$ month (April) $(6.98 \pm 0.18 \%)$, and after that increases constantly until the $11^{\text {th }}$ (November) month, i.e. until lactation ends, when is the highest $(9.03 \pm 0.34 \%)$.
Similar results were found for Awassi in Iraq (Alkass et al., 2008).

\section{Milk control number influence on daily milk production in Awassi sheep}

The number, i.e the order of milk control influences highly significant $(\mathrm{P}<0.001)$ on tested parameters, with exception of evening milking, which influences with slightly lower significance $(\mathrm{P}<0.05)$ (Table 5). Generally speaking, the morning milk production decreases constantly from the first up to the $9^{\text {th }}$ milk control (Table 10). The same tendency was noted with the total daily milk production. There is a slight deviation in this tendency, in the noon and evening milking, i.e. the milk production decreases in the noon milking from the first to the fifth milk control, after that increases in the $5^{\text {th }}$ and $6^{\text {th }}$ control and then decreases until the end of the lactation. In evening 
milking, the amount of milk increases and decreases permanently, but it is always from around 0.50 to 0.22 litres for the last milk control. Milk fat percent constantly increases from first to last milk control, i.e. it is in the range of $6.86 \pm 0.12 \%$ (in first) up to $8.00 \pm 0.32 \%$ (in last, $9^{\text {th }}$ milk control).

Table 9

The influence of the month of test on daily milk production in Awassi sheep, LS - mean $\pm S E$

\begin{tabular}{cccccccc}
\hline \hline Month of milk control & $n$ & $\begin{array}{c}\text { Morning } \\
\text { (litres) }\end{array}$ & $\begin{array}{c}\text { Noon } \\
\text { (litres) }\end{array}$ & $\begin{array}{c}\text { Evening } \\
\text { (litres) }\end{array}$ & $\begin{array}{c}\text { Total } \\
\text { (litres) }\end{array}$ & $\begin{array}{c}\text { Fat } \\
(\%)\end{array}$ & $\begin{array}{c}\text { Fat } \\
(\mathrm{kg})\end{array}$ \\
\hline 1 & 24 & $1.00 \pm 0.12$ & $0.18 \pm 0.08$ & $1.08 \pm 0.10$ & $2.26 \pm 0.22$ & $7.78 \pm 0.30$ & $0.18 \pm 0.02$ \\
2 & 37 & $0.89 \pm 0.10$ & $0.26 \pm 0.07$ & $0.85 \pm 0.10$ & $2.00 \pm 0.19$ & $7.20 \pm 0.26$ & $0.14 \pm 0.01$ \\
3 & 69 & $0.83 \pm 0.09$ & $0.51 \pm 0.06$ & $0.66 \pm 0.08$ & $2.00 \pm 0.16$ & $7.44 \pm 0.22$ & $0.15 \pm 0.01$ \\
4 & 141 & $0.82 \pm 0.07$ & $0.49 \pm 0.05$ & $0.61 \pm 0.06$ & $1.92 \pm 0.13$ & $6.98 \pm 0.18$ & $0.13 \pm 0.01$ \\
5 & 152 & $0.83 \pm 0.06$ & $0.37 \pm 0.04$ & $0.57 \pm 0.05$ & $1.77 \pm 0.11$ & $7.05 \pm 0.15$ & $0.12 \pm 0.01$ \\
6 & 166 & $0.79 \pm 0.05$ & $0.33 \pm 0.03$ & $0.50 \pm 0.04$ & $1.62 \pm 0.10$ & $7.18 \pm 0.13$ & $0.12 \pm 0.01$ \\
7 & 167 & $0.75 \pm 0.04$ & $0.07 \pm 0.03$ & $0.52 \pm 0.04$ & $1.34 \pm 0.08$ & $7.69 \pm 0.11$ & $0.10 \pm 0.01$ \\
8 & 167 & $0.57 \pm 0.04$ & $0.05 \pm 0.03$ & $0.48 \pm 0.03$ & $1.10 \pm 0.07$ & $7.42 \pm 0.10$ & $0.08 \pm 0.01$ \\
9 & 123 & $0.43 \pm 0.04$ & $0.01 \pm 0.03$ & $0.33 \pm 0.04$ & $0.77 \pm 0.08$ & $7.87 \pm 0.11$ & $0.06 \pm 0.01$ \\
10 & 79 & $0.37 \pm 0.05$ & $0.01 \pm 0.04$ & $0.10 \pm 0.05$ & $0.48 \pm 0.10$ & $8.22 \pm 0.14$ & $0.04 \pm 0.01$ \\
11 & 5 & $0.19 \pm 0.13$ & $0.026 \pm 0.10$ & $0.19 \pm 0.12$ & $0.41 \pm 0.25$ & $9.03 \pm 0.34$ & $0.04 \pm 0.02$ \\
\hline \hline
\end{tabular}

Table 10

The influence of the number of milk control on daily milk production in Awassi sheep, LS - mean $\pm S E$

\begin{tabular}{cccccccc}
\hline \hline No of milk control & $n$ & $\begin{array}{c}\text { Morning } \\
\text { (litres) }\end{array}$ & $\begin{array}{c}\text { Noon } \\
\text { (litres) }\end{array}$ & $\begin{array}{c}\text { Evening } \\
\text { (litres) }\end{array}$ & $\begin{array}{c}\text { Total } \\
\text { (litres) }\end{array}$ & $\begin{array}{c}\text { Fat } \\
(\%)\end{array}$ & $\begin{array}{c}\text { Fat } \\
(\mathrm{kg})\end{array}$ \\
\hline 1 & 170 & $0.82 \pm 0.05$ & $0.37 \pm 0.03$ & $0.57 \pm 0.04$ & $1.76 \pm 0.09$ & $6.86 \pm 0.12$ & $0.12 \pm 0.01$ \\
2 & 170 & $0.79 \pm 0.04$ & $0.35 \pm 0.03$ & $0.54 \pm 0.04$ & $1.68 \pm 0.07$ & $7.34 \pm 0.10$ & $0.12 \pm 0.01$ \\
3 & 170 & $0.68 \pm 0.04$ & $0.23 \pm 0.03$ & $0.49 \pm 0.03$ & $1.40 \pm 0.07$ & $7.53 \pm 0.10$ & $0.11 \pm 0.01$ \\
4 & 163 & $0.63 \pm 0.04$ & $0.12 \pm 0.03$ & $0.54 \pm 0.04$ & $1.29 \pm 0.08$ & $7.61 \pm 0.10$ & $0.10 \pm 0.01$ \\
5 & 152 & $0.65 \pm 0.05$ & $0.10 \pm 0.03$ & $0.53 \pm 0.04$ & $1.28 \pm 0.09$ & $7.76 \pm 0.12$ & $0.10 \pm 0.01$ \\
6 & 143 & $0.56 \pm 0.06$ & $0.13 \pm 0.04$ & $0.49 \pm 0.05$ & $1.18 \pm 0.11$ & $7.87 \pm 0.15$ & $0.09 \pm 0.01$ \\
7 & 106 & $0.49 \pm 0.07$ & $0.18 \pm 0.10$ & $0.51 \pm 0.06$ & $1.18 \pm 0.13$ & $7.79 \pm 0.19$ & $0.09 \pm 0.01$ \\
8 & 46 & $0.35 \pm 0.09$ & $0.15 \pm 0.06$ & $0.40 \pm 0.08$ & $0.9 \pm 0.16$ & $7.86 \pm 0.22$ & $0.07 \pm 0.01$ \\
9 & 10 & $0.20 \pm 0.12$ & $0.13 \pm 0.08$ & $0.22 \pm 0.11$ & $0.55 \pm 0.23$ & $8.00 \pm 0.32$ & $0.04 \pm 0.02$ \\
\hline \hline
\end{tabular}

The trend of constant decrease in the daily milk yield is typical for most of the dairy sheep populations. In contrast the studies in the Israelian Awassi showed an increase of the daily yield to a certain point, followed by a decrease (Gootwine and Pollott, 2000).

\section{Fertility influence on daily milk production in Awassi sheep}

The fertility, i.e. the number of lambs born per sheep in Awassi has significant $(P<0.05)$ in- fluence on the evening and total daily milk, as well as on the amount of produced milk fat. This factor did not have influence $(\mathrm{P}>0.05)$ on the rest of the tested traits (Table 5). The Awassi sheep which delivered two lambs had slightly higher daily milk production (1.45 \pm 0.09 litres) compared to those with one lamb $(1.33 \pm 0.08$ litres $)$. The milk fat percent is insignificantly higher in sheep with one lamb $(7.63 \pm 0.11 \%)$, compared to those with twin lambs $(7.61 \pm 0.12 \%)$, (Table 11). 
Table 11

The influence of the fertility on the daily milk production in Awassi sheep, LS - mean $\pm S E$

\begin{tabular}{cccccccc}
\hline \hline Fertility & $n$ & $\begin{array}{c}\text { Morning } \\
\text { (litres) }\end{array}$ & $\begin{array}{c}\text { Noon } \\
(\text { litres })\end{array}$ & $\begin{array}{c}\text { Evening } \\
(\text { litres })\end{array}$ & $\begin{array}{c}\text { Total } \\
(\text { litres })\end{array}$ & $\begin{array}{c}\text { Fat } \\
(\%)\end{array}$ & $\begin{array}{c}\text { Fat } \\
(\mathrm{kg})\end{array}$ \\
\hline 1 & 996 & $0.66 \pm 0.04$ & $0.19 \pm 0.03$ & $0.48 \pm 0.04$ & $1.33 \pm 0.08$ & $7.63 \pm 0.11$ & $0.10 \pm 0.01$ \\
2 & 134 & $0.70 \pm 0.05$ & $0.22 \pm 0.03$ & $0.53 \pm 0.04$ & $1.45 \pm 0.09$ & $7.61 \pm 0.12$ & $0.11 \pm 0.01$ \\
\hline \hline
\end{tabular}

\section{CONCLUSIONS}

Based on data from this research the following conclusions can be made:

The high influence on milk control number $(\mathrm{P}<0.01)$ on tested traits in Awassi sheep points out the typical lactation curve, characteristic for dairy population sheep, which starts with the highest daily milk production during the first milk control, and the lowest during the last one.

The simultaneous analyses of several factors (year, lactation, lambing month, milk control month, and milk control number) on the daily milk production (morning, noon, evening, total), as well as the percent and milk fat production showed significant influence for most of them.

The effect of lactation number showed that the Awassi breed maintained the level of high and standard milk production until older age of $7^{\text {th }}-8^{\text {th }}$ lactation.

\section{REFERENCES}

[1] Alkass J. E., Al-Rawi A. A., Al-Mohammadi D. S. H.: Evaluation of test-day milk yield in some commercial Awassi sheep flocks. Egyptian Journal of Sheep and Goat Sciences, Vol. 3, No. 2, pp. 19-26 (2008).

[2] Amin Y. M., Peters, J. K.: Awassi sheep production and the development of breeding program options in Syria. 57-th Annual Meeting of the European Association for Animal Production (EAAP) 17-20 September, 2006 Antalya, Turkey. Book of abstracts, No $12: 81$ (2006).

[3] Caja G., Milan J. M., Gonzales R., Fernandez M. A.: Structure and performance of Awassi and Assaf dairy sheep farms in the NW of Spain. 57-th Annual Meeting of the European Association for Animal Production (EAAP) 17-20 September, 2006. Antalya, Turkey. Book of abstracts, No $12: 80$ (2006).

[4] Cappio-Borlino A., Portolano B., Todaro M., Macciotta N. P., Giaccone P., Pilina G.: Lactation Curves of Valle del Belice Dairy Ewes for Yields of Milk, Fat, and Protein Estimated with Test Day Models. J. Dairy Sci., 80 : 3023-3029, (1997).

[5] De la Fuente, F. L., Gabina, D., Carolino, N., Ugarte, E.: The Awassi and Assaf breeds in Spain and Portugal. 57- th Annual Meeting of the European Association for Animal Production (EAAP) 17-20 Septembar, 2006. Antalya, Turkey. Book of abstracts, No 12 : 79 (2006).

[6] Epstein, H.: The Awassi sheep with special reference to the improved dairy type. FAO Animal production and health paper, No 57, pp. 1-284. Rome, Italy (1985).

[7] FAO.: The State of the World's, Animal Genetic Resources for Food and Agriculture. Commission on Genetic Resources for Food and Agriculture, pp. 1-511. Rome (2007).

[8] Gootwine, E.: Increasing prolificacy of the fat tail Awassi sheep using the Booroola FecB gene. Strategies for sheep and goat breeding. Proceedings of the Meeting of the Joint FAO/CIHEAM Network on Sheep and Goats, Subnetwork on Animal Resources, 26-28 March, 1995, pp. 79-87, 9 ref, Sidi-Thabet, Tunisia (1995).

[9] Gootwine E., Pollott E. G.: Factors affecting milk production in improved Awassi dairy ewes. Animal Science 71 : 607-615 (2000).

[10] Gursoy, O., Kirk, K., Cebeci, Z., Pollott, E. G.: Genetic evaluation of growth performance in Awassi sheep. Cahiers, Options Mediterranes. Strategies for sheep and goat breeding. FAO, CIHEAM, OEP. Vol. 11, pp. 193201 (1995).

[11] Hristov H. M.: Fenotype and genetic parmeters of Awassi sheep in Bulgaria. PhD thesis. Rural Economic Academy, pp. 1-140. Sofia. Bulgaria (1983).

[12] ICAR: International Agreement of Recording Practices. Guidelines approved by the General Assembly, pp. 1580. Cork, Ireland, June, 2012.

[13] Iniguez L., Hilali M., Jessr G.: Evaluation of Awassi genotypes for milk production improvement. 57-th Annual Meeting of the European Association for Animal Production (EAAP) 17-20 September 2006. Antalya, Turkey. Book of abstracts, No 12 : 91 (2006).

[14] Kosgey I.: Breeding objectives and breeding strategies for small ruminants in the tropics. $\mathrm{PhD}$ thesis. Wageningen, Netherlands (2004).

[15] Kukovics, S., Dimov, D., Kume, K., Pacinovski, N.: Exploitation of Awassi sheep breed in the Central, Eastern and South European country. 57-th Annual Meeting of the European Association for Animal Production (EAAP). 17-20 September 2006, Antalya, Turke, Book of abstracts, No 12 : 79, (2006).

[16] Mavrogenis P. A.: Breeding systems and selection strategies for sheep improvement in Cyprus. Cahiers, Options Mediterranes, Seminaires Mediterranean, Sidi-Thabet (Tunisia), 26-28 March, Vol. 11, pp. 17-27, 2 ref. (1995)

[17] Mckusick C. B., Thomas L. D., Berger M. Y.: Effect of Weaning System on Commercial Milk Production and 
Lamb Growth of East Friesian Dairy Sheep. J. Dairy Sci., 84:1660-1668 (2001).

[18] Mekič C., Petrovič P. M., Trifunovič G.: Curent situation and perspective in sheep milk improvement. Biotechnology in Animal Husbandry, 21, pp. 15-28 (2005).

[19] Nudda A., Bencini R., Mijatovic S., Pulina G.: The Yield and Composition of Milk in Sarda, Awassi, and Merino Sheep Milked Unilaterally at Different Frequencies. $J$. Dairy Sci., 85:2879-2884 (2002).

[20] Pacinovski N.: Influence of some factors on the udder measurements in Awassi sheep and its crossbreeds with Domestic population sheep in Macedonia. Krmiva, 52, 2, 85-93 (2010).

[21] Petrovič P. M., Mekič C., Ruzič Dragana, Zujovič M.: Testing the heritability and genetic correlation of lactation characteristics of sheep. Biotechnology in Animal Husbandry, 21 (3-4). 55-60 (2005).

[22] SPSS: SPSS 6.1 for Windows Student Version. Chicago, USA (1994).

[23] Srour G., Abi Saab S., Marie M.: Awassi productivity under different production systems in Lebanon. 57-th Annual Meeting of the European Association for Animal
Production (EAAP), 17-20 September 2006, Antalya, Turkey. Book of abstracts, No 12 : 81, (2006).

[24] Todorovski N., Ristevski K., Popovski K.: Contribution to the knowledge of lactation of Awassi sheep conditioned with lactation curve. Stockbreeding, 27 (5-6), 239-243 (1973).

[25] Todorovski N., Ristevski K., Popovski K.: Lactation and milk fat of Awassi sheep on individual sector of Republic of Macedonia. Stockbreeding, 33 : 267-275 (1979).

[26] Todorovski N., Petev A., Djabirski V., Abd Ahmed H.: Lactation and milk fat of Awassi sheep and their crossbreed on individual sector. Stockbreeding, 38 (1-2), 4954 (1984).

[27] Todorovski N., Pesheva V., Petev A., Djabirski V., Abd Ahmed H.: Lactation and milk fat of Awassi sheep and their crossbreeds on newly formed sheep farm RIK 'Sileks' Kratovo. Stockbreeding, 39 (11-12), 387-398 (1985).

[28] Todorovski N., Mickovski Gj, Popovski K., Kozarovski N.: Comparative production values of Awassi breed regarding the domestic sheep pramenka. Meeting Faculty Economy, Skopje. Macedonia (1996). 